Scientific Journal of Silesian University of Technology. Series Transport Zeszyty Naukowe Politechniki Śląskiej. Seria Transport

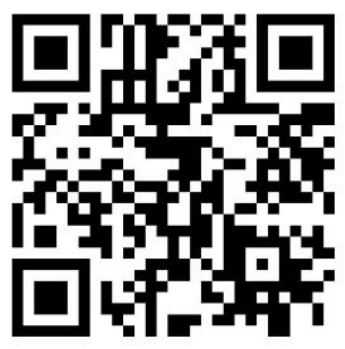

Volume 113

2021

p-ISSN: 0209-3324

e-ISSN: 2450-1549

DOI: https://doi.org/10.20858/sjsutst.2021.113.6

Journal homepage: http://sjsutst.polsl.pl

Article citation information:

Gorzelanczyk, P., Polak, I. Forecasting the load on night bus lines: a case study of the municipal transport company in Pila. Scientific Journal of Silesian University of Technology. Series Transport. 2021, 113, 75-90. ISSN: 0209-3324.

DOI: https://doi.org/10.20858/sjsutst.2021.113.6.

Piotr GORZELANCZYK ${ }^{1}$, Ida POLAK ${ }^{2}$

\title{
FORECASTING THE LOAD ON NIGHT BUS LINES: A CASE STUDY OF THE MUNICIPAL TRANSPORT COMPANY IN PIIA
}

Summary. The main purpose of this article is to make a forecast of the load on the night lines using the Municipal Transport Company in Piła (MTC) as a case study. This article characterizes the concept of urban logistics and mobility, and then proposed a mobility model that considers the preferences of residents when choosing a means of transport. Finally, it ends with a survey and the appropriate conclusions drawn.

Keywords: night bus lines, urban transport, Piła

\section{INTRODUCTION}

The essence of logistics is the flow of material goods and information as well as their intensity, continuity and reliability [1]. The spatial concentration of industry, trade and services in a small area always creates smaller or larger problems with their functioning. These are mainly difficult transfer, storage and punctual delivery processes. That is why in the 1980s and 1990s, the concept of urban logistics was used for the first time. From English, "city logistics" is a tool for solving problems related to traffic pathology in highly urbanized areas [2].

\footnotetext{
1 Stanislaw Staszic University of Applied Sciences in Pila, Podchorazych 10 Street, 64-920 Pila, Poland. Email: piotr.gorzelanczyk@ puss.pila.pl. ORCID: https://orcid.org/0000-0001-9662-400X

2 Stanislaw Staszic University of Applied Sciences in Pila, Podchorazych 10 Street, 64-920 Pila, Poland. Email: ida.polak@o2.pl. ORCID: https://orcid.org/0000-0001-8692-5618
} 
Urban logistics is a broadly understood concept because it has many definitions. The simplest explanation is understood as the optimization of the city's system in terms of planning, control and supervision. It depends, of course, on technological, social, economic and ecological conditions. The definition developed by the Council of Logistics Management speaks in detail about initiating the movement that occurs in the city for the needs of residents. These include traffic from outside the city to the inside, traffic from inside the city to the outside, and traffic that takes place inside the city. Urban logistics ensures the organization of municipal services provided to business entities and the population [3-5], as well as managing the flow of people, loads and information with ecological, material and information security $[6,7]$.

The goal of urban logistics is to combine all economic entities into one unit. This ensures an adequate standard of living and farming with minimal costs and little damage to the ecology. Therefore, three main goals of urban logistics can be distinguished: economic, ecological and social. A look at the overall functioning of the city allows one to eliminate unnecessary transport, reduce travel time, segregate traffic, reduce inventory, and manage waste.

The concept of mobility is closely related to urban logistics. Mobility is defined differently by various authors. Szołtysek treats [8] mobility as a daily, routine movement and activities resulting from the reorganization of one's personal life, which may include a change of residence or workplace. We can identify it with the movement and all activity of people carried out using transport outside their place of residence [9, 10]. In contrast, Menes [11] presents mobility as mobility associated with the daily movements of residents, usually to work or school.

According to the authors of this publication, mobility is the daily routine movement of residents related to their existence. Subsequently, this wording was later adopted in this article.

The daily bus route is a permanent communication link between the road networks and designated stops. The bus runs according to a scheduled timetable from around 5:00 to around 23:00. On the other hand, the night bus route is no different from a regular bus route outside the hours of the service. The courses are carried out from around 23:00 to 5:00. [12]

The timetable, also known as the bus timetable, informs people using communication about the arrival/departure time and stops along the course route. Each bus line has its own individual timetable. It is not the same all week. It is usually divided into 3 parts: the Monday to Friday timetable, the Saturday timetable and the Sunday timetable. Such a division prevails throughout Poland [13].

Currently, night lines are a common means of transport created in large cities. It makes it easier for young people (mainly students) to meet up with friends, and people working back home. This method is much safer than walking and relatively cheaper than using a car or a taxi. This type of solution in a large or growing city is necessary. It facilitates movement and, at the same time, by excluding a large number of used vehicles, contributes to environmental protection, which has recently been an important topic.

Night lines are the standard of all major cities because they significantly simplify the lives of residents. They operate, among others, in Poznań, where there are 23 night bus lines and 1 tram line. The frequency of travel is once every 30 minutes. Also in Warsaw, there are 43 night bus lines, which run on average up to 15-20 minutes. In addition, the night bus service is supported by trams and the metro. Similarly, there are night lines in Wroclaw with 16 bus lines. Buses run all night every half hour, while trams have an extended journey time until 00:30 [1317]. 
In the analyzed city, which is Piła, communication at night operates during one night of the year when the Museum Night takes place. It is a route specially prepared for residents giving the opportunity to get to the two museums of the city. There are two lines: A and B. The frequency of the courses is once per hour.

The proper functioning of the city depends on many elements. Each of them is relevant and dependent on each other. When one stops working, the rest have a difficult job. Over the years, each area has developed its own urban logistics. Well designed, it prevents city congestion, creates liquidity and no delays, and at the same time, due to increasingly new technological solutions, it has become more ecological.

\section{CHARACTERISTICS OF THE CITY OF PILA AND THE MUNICIPAL TRANSPORT COMPANY IN PILA}

Piła is a city located in northwest Poland in the Greater Poland Voivodeship. Currently, it has about 70,000 inhabitants, and its area is $102.68 \mathrm{~km}^{2}$. According to data from 2017, the most populated areas are Górne (about 13,000), Zamość (about 19,500), and Śródmieście (about 14,000). The smallest number of inhabitants is Gładyszewo (around 500) with Motylew (around 900). Moderate population occurs in the following districts: Jadwiżyn (about 5,000), Koszyce (about 5,000), Podlasie (about 6,000) and Staszyce (about 6,000) [18].

The history of Piła urban transport dates back to the 1920s when the first 3 lines operated. During World War II, the city was so damaged that it was not reopened until July 1, 1957. By the decision of the Provincial National Council in Poznan, the Municipal Transport Plant was established at the Municipal Enterprise of Economy in Piła. Initially, it was located at 10 Kujawska Street. Presently, it is located at 4 Lączna Street [19].

On December 29, 2000, the Miejski Zakład Komunikacji Limited Liability Company in Piła was officially formed following the transformation. Then, apart from the old rolling stock, the company already had 2 new Neoplan N4009 buses and 8 Neoplan N4016 buses.

There are currently 24 bus lines in Piła. Below is a diagram of communication lines. At designated times and seasons based on several years of research, they are shortened or extended. The current scheme of public transport lines is shown in Figure 1.

On January 30, 2021, MTC rolling stock in Piła had 47 buses. There are three main brands that MTC purchases the most. They are Solaris, Neoplan and Mercedes. Table 1 below presents the entire fleet of MTC in Piła as of 30.01.2021 [19].

Tab.1.

Rolling stock MTC [19]

\begin{tabular}{|c|c|c|c|c|c|}
\hline Bus type & $\begin{array}{c}\text { Adapted to people } \\
\text { with disabilities }\end{array}$ & $\begin{array}{c}\text { Date of } \\
\text { production }\end{array}$ & $\begin{array}{c}\text { Date of } \\
\text { purchase }\end{array}$ & $\begin{array}{c}\text { The number } \\
\text { of the bus }\end{array}$ & $\begin{array}{c}\text { The number } \\
\text { of items }\end{array}$ \\
\hline Jelcz 120M & No & 2000 & 2000 & $363,364,365$ & 3 \\
\hline Mercedes Citaro & Yes & $\begin{array}{c}1998,2000, \\
2003,2004\end{array}$ & $\begin{array}{c}2012, \\
2013,2014\end{array}$ & $406-411$ & 6 \\
\hline Neoplan N4016 & Yes & 1998 & 1998 & $354,355,359$ & 3 \\
\hline Neoplan N4411 & Yes & 2002,2003 & 2010 & $396-401$ & 6 \\
\hline Solaris Urbino 10 & Yes & 2003,2011 & 2004,2011 & $372-374,404$ & 4 \\
\hline
\end{tabular}




\begin{tabular}{|c|c|c|c|c|c|}
\hline Solaris Urbino 12 & Yes & $\begin{array}{c}2005-2007, \\
2009,2010 \\
2011,2016 \\
2017\end{array}$ & $\begin{array}{c}2005-2007, \\
2009 \\
2010, \\
2011, \\
2016,2017\end{array}$ & $\begin{array}{l}377-380, \\
382-395, \\
402-403, \\
412-416\end{array}$ & 25 \\
\hline $\begin{array}{c}\text { Solaris Urbino } 12 \\
\text { Hybryd }\end{array}$ & Yes & 2017 & 2017 & $420-425$ & 6 \\
\hline \multicolumn{5}{|c|}{ The number of all buses } & 53 \\
\hline \multicolumn{5}{|c|}{ The share of buses adapted for the disabled in the fleet } & $93 \%$ \\
\hline \multicolumn{5}{|c|}{ The average age of the operated bus fleet } & 11 years \\
\hline
\end{tabular}

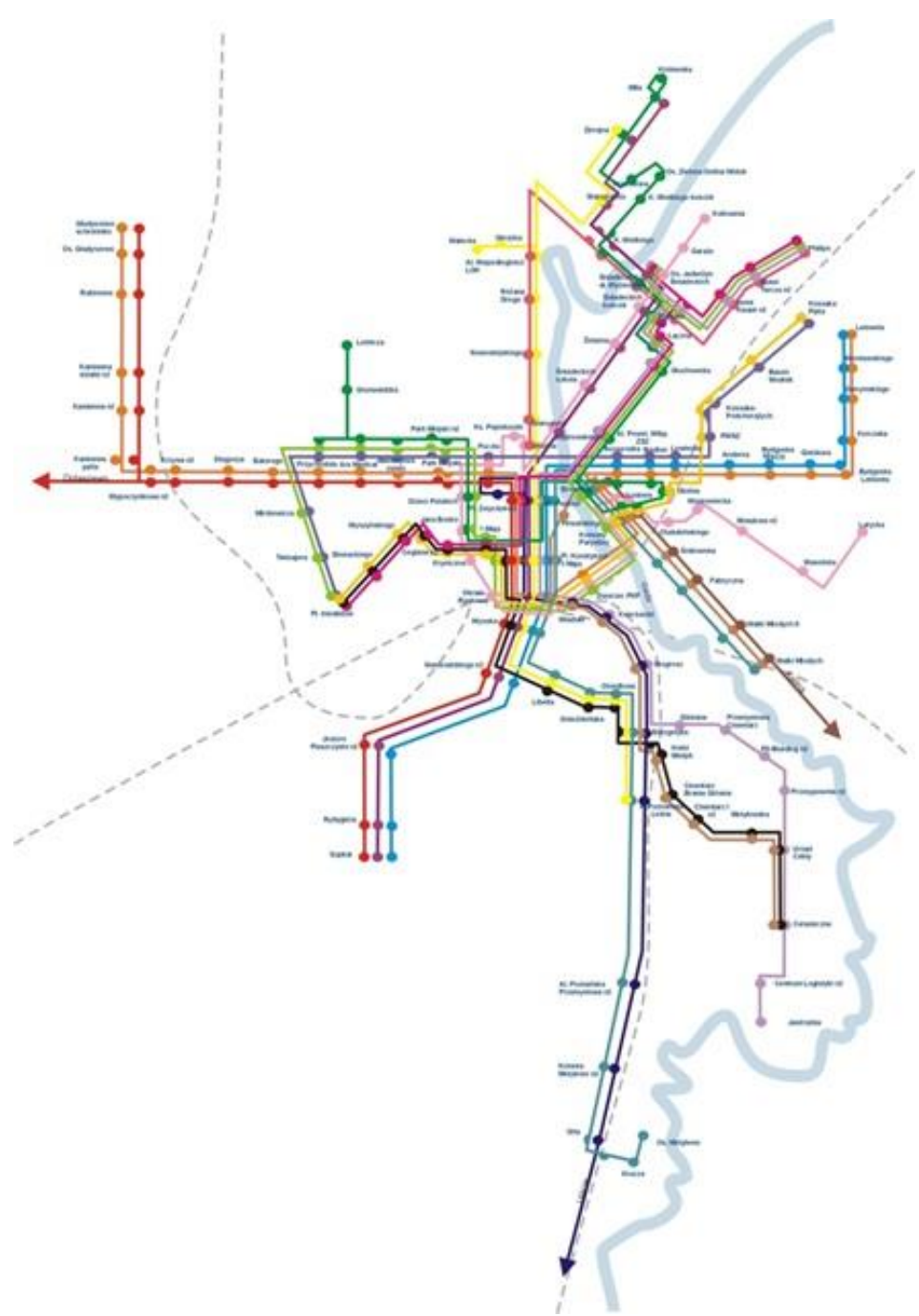

Fig. 1. Timetables of bus lines in the city of Piła [19]

\section{GENERALIZED MOBILITY MODEL}

Considering the objectives of transport activities and the preferences of residents, we can assume that we can define the mobility model of city users using the following elements [20]:

- user bases - BU,

- mobility structures - SM, 
- choice of means of transport - ST,

- a database of characteristics of BM mobility structure elements,

- travel organization - OP,

- residents' preferences - PM.

Given the above elements of mobility, the mobility model - MM can be presented in the form of the equation:

$$
M M=<B U, S M, S T, B M, O P, P M>
$$

In the above model, the set of users takes the form:

$$
U=\{1, \ldots, U\}
$$

where:

$U-$ is the number of users of the studied mobility.

However, the user was described by vector:

$$
\overrightarrow{F(u)}=p(u), g w(u), m z(u)
$$

where:

$p(u)$ - user gender,

$g w(u)$ - the user's age group,

$m z(u)$ - user residence,

City user gender: assumed $(p(u)=1)$ for a woman and $(p(u)=2)$ for a man, while the set of age group numbers:

$$
g w=\{1, \ldots, G W\}
$$

determines the age of the user. In this case, it was assumed: gw $(\mathrm{u})=1-\mathrm{up}$ to 16 years, $\mathrm{gw}(\mathrm{u})$ $=2-16 \div 19$ years, gw $(\mathrm{u})=3-20 \div 25$ years, gw $(\mathrm{u})=4-26 \div 40$ years, gw $(\mathrm{u})=5-$ over 40 years.

Where:

$G W$ - determines the number of all surveyed age groups, in this case, equal to 6 .

Then the residents were divided according to their place of residence $\mathrm{mz}(\mathrm{u})$. For example $(\mathrm{mz}(\mathrm{u})=1)$ - Piła, $(\mathrm{mz}(\mathrm{u})=2)$ - Dobrzyca, $(\mathrm{mz}(\mathrm{u})=3)$ - Złotów, etc. In this case, the formula takes the form:

$$
m z=\{1, \ldots, M Z\}
$$

where:

$M Z$ - determines the number of all residences equal 6.

The next element considered is the user base, which takes the form of the following vector: 


$$
\overrightarrow{B U}=\{U, F(u)\}
$$

The structure of mobility of residents in the mobility model of city users has been presented in the form of:

$$
S M=\{P M, P T\}
$$

where:

$P M$ - is the mobility point

$P T-$ collection of transport connections.

The places of activity of city users (for example, place of residence, workplace or school) were taken as the mobility points, that is, the starting and ending point of travel. These also include intermediate points (for example, stations, stops, parking lots, etc.) known as intermediate points. Each component included in the residents' mobility structure contains characteristics specific to transport activities such as, for example, waiting time at the stop, parking cost, etc.

Another of the discussed mobility component is the choice of the means of transport, which we can present in the form of:

$$
S T=\{c p, k p, k d, b s t, d s t, w b, p s t, z i, c k, s y, o s ́\}
$$

where:

$c p$ - travel time,

$k p$ - the cost of travel,

$k d$ - travel comfort (in this case, the traveler can count on, among others, rest, eating a meal, comfortable seating),

$b s t$ - travel safety,

$d s t$ - availability of means of transport (we can include here extensive point infrastructure, for example, bus and railway stations, passenger terminal, number of connections per day),

wb - luggage size,

$p s t$ - punctuality of the means of transport,

$z i$ - source of information on the timetable,

$c k$ - travel frequency,

sy - synchronization with other means of transport,

$o s ́$ - environmental protection.

The last of the considered mobility elements is the base of characteristics of elements of the mobility structure defined in the form:

$$
B M=\{Z C P M, Z C P T\}
$$

where:

$Z C P M$ - referred to as the set of characteristics described at mobility points, $Z C P T$ - referred to as the set of characteristics described on transport connections.

The next of the discussed elements is the organization of the travels of the OP. The model assumes two variants of travel organization: 
where:

$$
O P=\{1,2\}
$$

$O P=1-$ means a one-step variant,

$O P=2-$ means a three-stage variant.

A one-stage journey is very rare, only if someone travels on foot. We can describe it in the form of:

$$
O P 1=\{p p, p k\}
$$

where:

$p p$ - is the starting point of the trip,

$p k-$ is the end point of the journey.

Usually, the three-stage journey consists of the following elements: walking, for example, reaching the stop, public transport, and walking to the destination. We can describe this kind of travel in the form of a vector:

$$
\overrightarrow{O P 2}=\{(p p, n 1),(n 1, n 2),(n 2, p k)\}
$$

where:

$n 1, n 2$ - waypoint number.

Considering the mobility model of residents together with their preferences, presented in formula (1), research on the preferences of residents was started.

\section{EXAMINATION OF THE CONCEPT OF INTRODUCING NIGHT LINES IN PILA}

\subsection{Purpose and scope of research}

The purpose of the survey was to find out the opinions of residents and people commuting to Piła on the introduction of night lines in the city of Piła. The survey was addressed mainly to students because they are young people with a completely different view of the environment than the older people. This study was to answer the question whether the introduction of night lines is justified. The questions were short and did not require complicated answers. The survey has been arranged so that as many people as possible complete it with the least amount of time.

\subsection{Research methodology}

The research was conducted in the form of surveys. In the beginning, a pilot study was carried out, based on which the question sheet was corrected. Then the survey was carried out at the following entities:

- Signify Piła,

- Complex of Economic Schools in Piła,

- School Complex at Teatralna in Piła,

to learn the opinions of people using public transport. 
The survey consisted of 14 closed questions that asked, among others, about sex, age, place of residence. The questions also concerned the desire to use the night line, the price of the night ticket and the housing estates where the night line should be introduced. At the end of the study, each of the respondents had the opportunity to propose MTC development directions. In total, 320 people were surveyed.

\subsection{Research object}

Based on the research, it was observed that in the group of 320 people, $48 \%$ were men and $52 \%$ were women. The most numerous group were young people between 16 and 19 years old. They constituted as much as $72 \%$. This is due to the places where the surveys were carried out, that is, two high schools. People over the age of 20 constitute only $28 \%$ of the respondents they were employees of Signify. The results are presented in Figure 2.

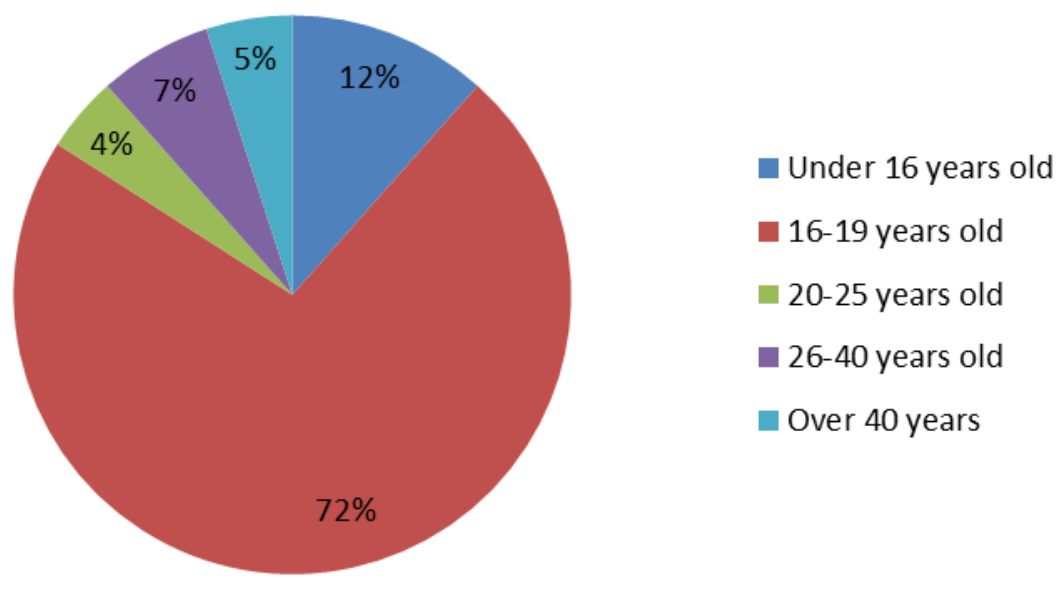

Fig. 2. Age range of respondents

Another question concerned the place of residence. The percentage share of people living in the city of Piła was dominant. It accounts for up to 59\%. The second largest group are people who marked "Other" - 17\%. They were people living in, among others, Osiek, Nakło nad Notecią, Kaczory, Białośliwie, Wysoka, and Radawnica. The small groups are other people residing other than those listed above. The results are presented in Figure 3.
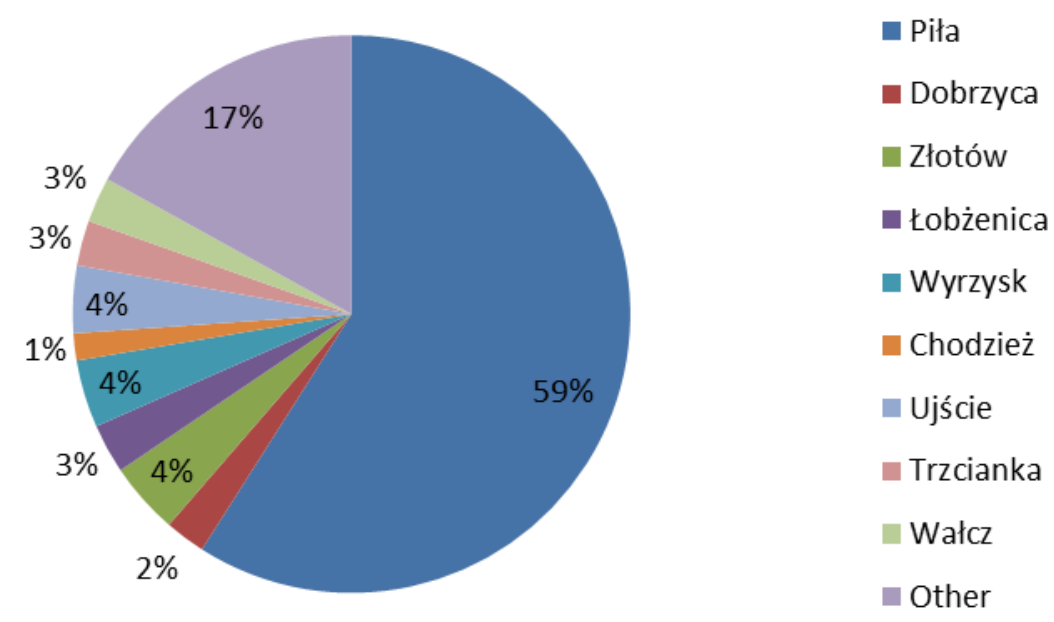

Fig. 3. Place of residence of the respondents 
Another question concerned the frequency of using public transport. As much as $25 \%$ of respondents marked the answer "several times a year", 24\% "daily", 22\% "several times a week", $16 \%$ "several times a month" and $13 \%$ "not at all". Surveys of people who answered this question "not at all" were not considered in further studies. In this question, the answers are evenly distributed. The results are presented in Figure 4.

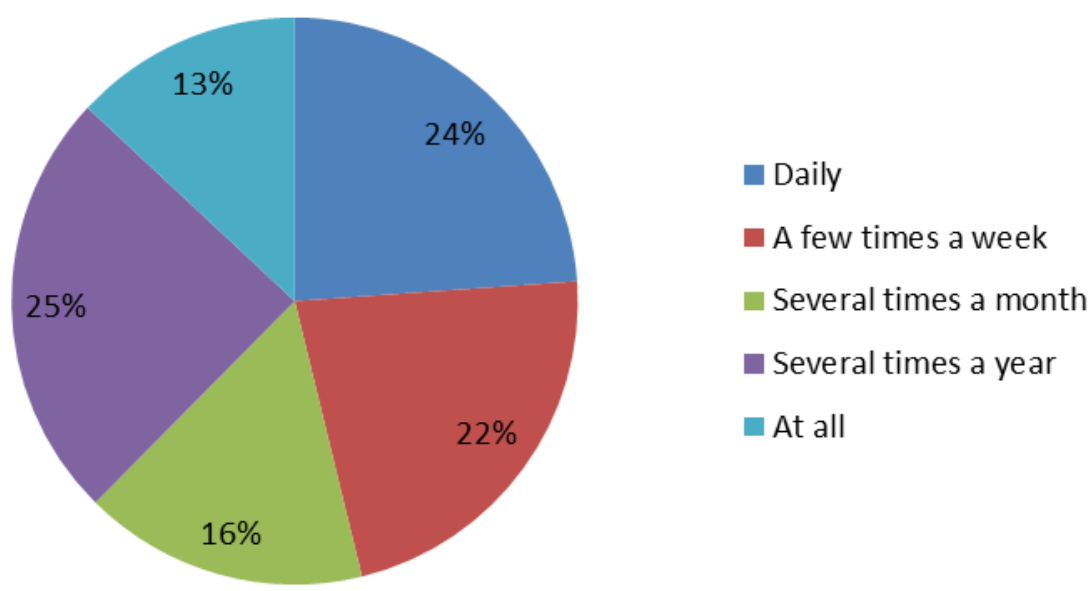

Fig. 4. Frequency of using MTC Piła

The next question concerned the hours of using MTC. Usually, respondents use public transport between 14:00 - 18:00. This answer was given by $36 \%$ of the respondents. The answer with hours of use 4:00 - 8:00 is 22\%. Hours of use between 4:00 - 13:00 and 19:00 - 23:00 were marked by the same number of respondents - they constitute $21 \%$ each. The results are presented in Figure 5.

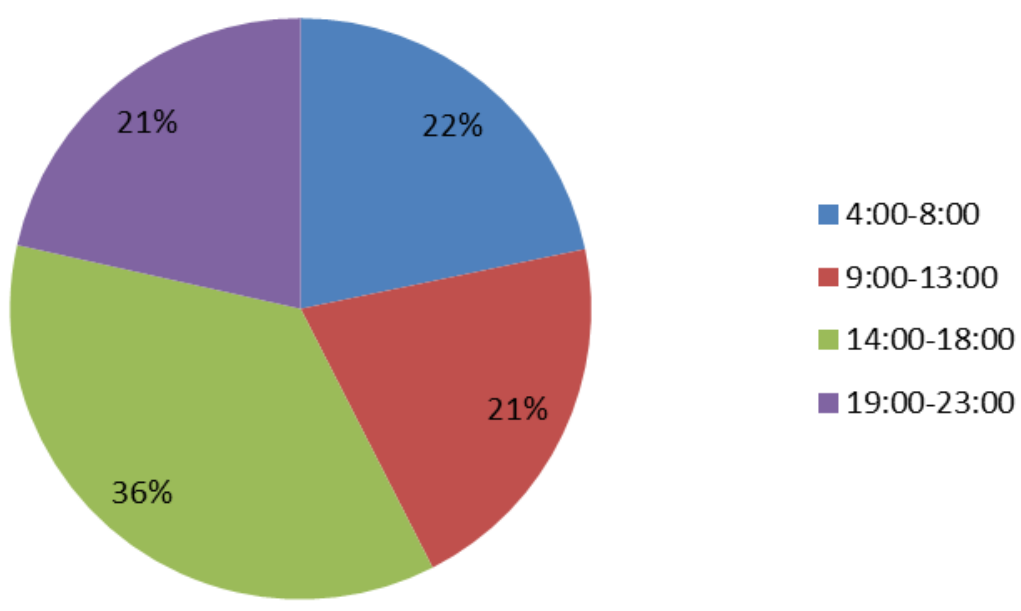

Fig. 5. Hours of use of MTC Piła respondents

The leading answer to the question about the destination is "travel to/from school" and "family/friends". Both answers were given by $31 \%$ of respondents. While $19 \%$ answered "shopping", $10 \%$ "commuting to / from work" and 7\% "health". Answers in the "Other" category (2\%) are extracurricular activities. The results are presented in Figure 6. 


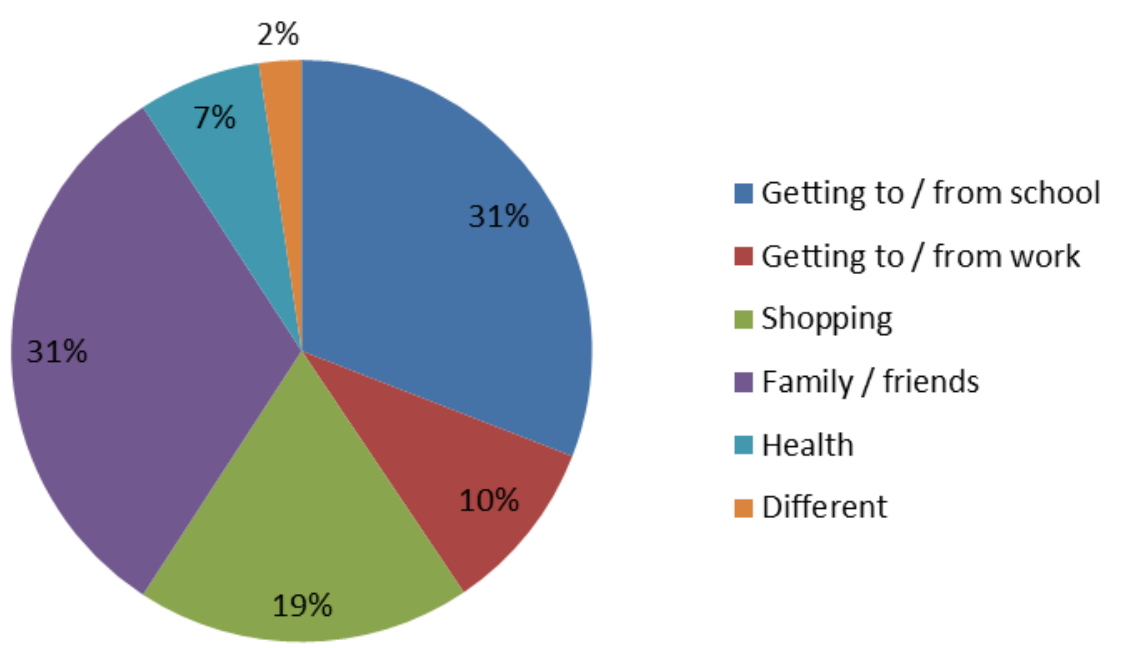

Fig. 6. Travel destination of MTC Piła users

People choosing the MTC chose time (33\%), price (24\%) and convenience (23\%) as the main choice factor. The least people considered punctuality $(8 \%)$ and environmental protection $(5 \%)$. The "Other" factor accounts for $7 \%$ of the answer - this is due to the lack of a driving license. The results are presented in Figure 7.

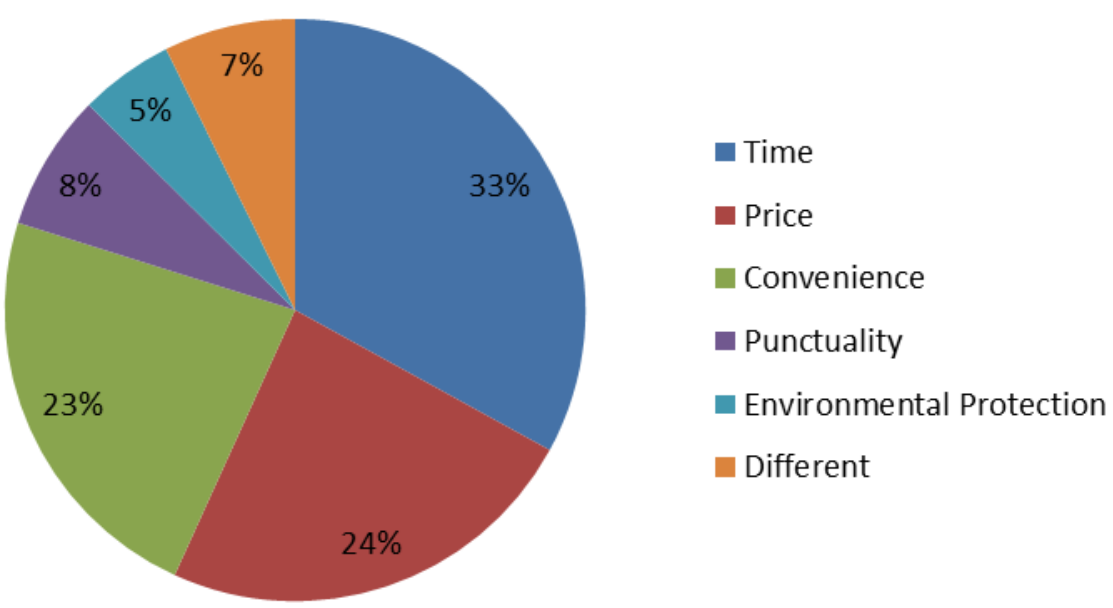

Fig. 7. The deciding factor in choosing MTC Piła

The level of satisfaction with the services provided by MTC is high - 16\% of the respondents answered "satisfied" and as many as $70 \%$ rather satisfied. This works for the company. Only $14 \%$ of the participants indicated a negative answer about the degree of satisfaction with the transport company. The results are presented in Figure 8. 


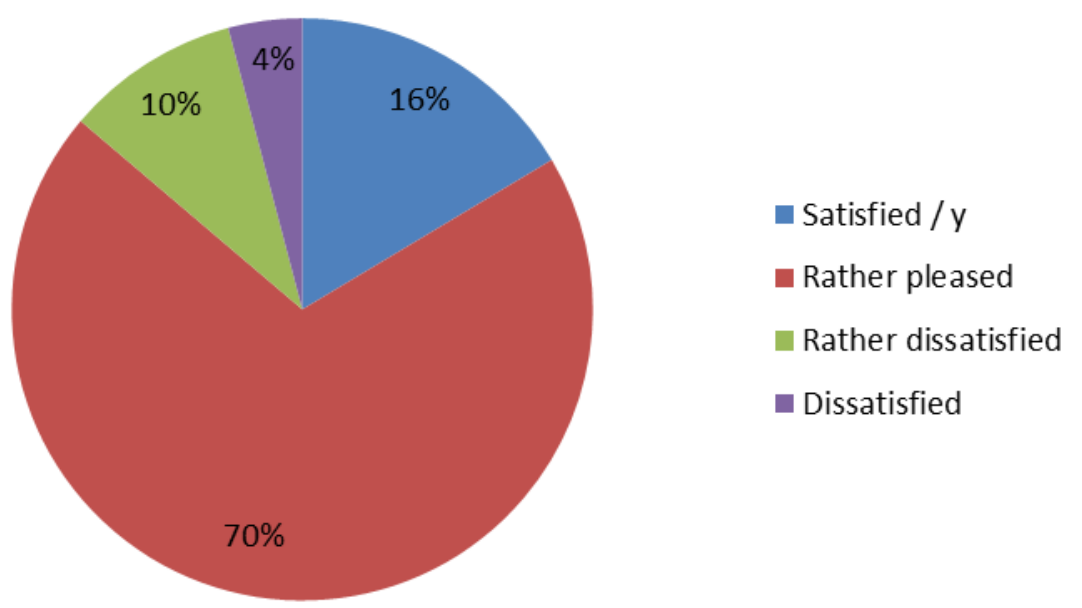

Fig. 8. The degree of satisfaction with the services provided by MTC Piła

To the next question about the desire to use night lines upon their introduction, more than half of the respondents (57\%) answered in the affirmative, while $43 \%$ answered in the negative. This means that most of the respondents are for the development of the company and the use of night lines. If any of the respondents gave a negative answer to this question, their survey was not considered in further studies. The results are presented in Figure 9.

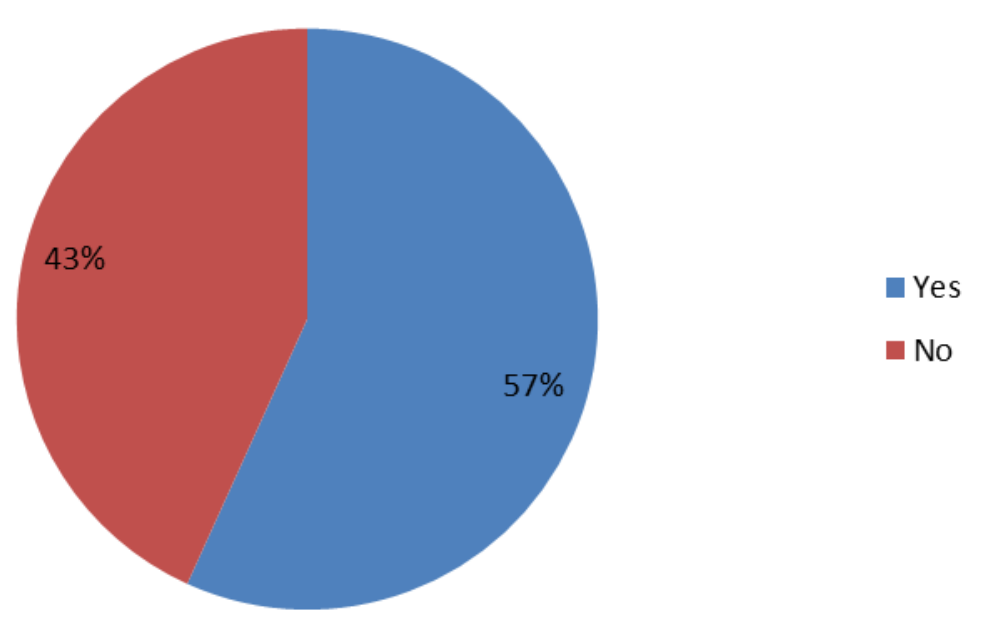

Fig. 9. Interest in introducing night lines in the city of Piła

When asked whether despite the introduction of a higher rate for a ticket, the respondent would still be interested in using it, $80 \%$ of respondents said yes. The results are presented in Figure 10. 


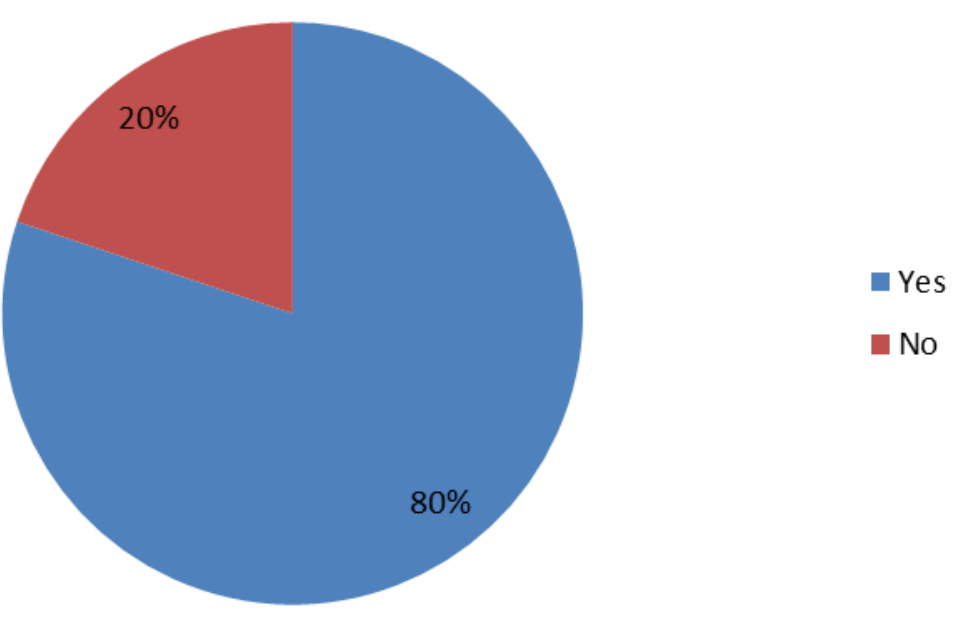

Fig. 10. Interest in using night lines in Piła despite the introduction of a higher rate for the ticket

The Śródmieście district enjoys the greatest interest among passengers departing from the night line $(25 \%)$. Here, the city's main nightlife and social life take place. The next districts with the most selections are Górne (14\%), Zielona Dolina (11\%), Podlasie (11\%) and Zamość $(10 \%)$. Districts with less than 10\% interest among passengers are Jadwiżyn, Koszyce / Zalew Koszycki, Motylewo, Gładyszewo, and Staszyce. The results are presented in Figure 11.

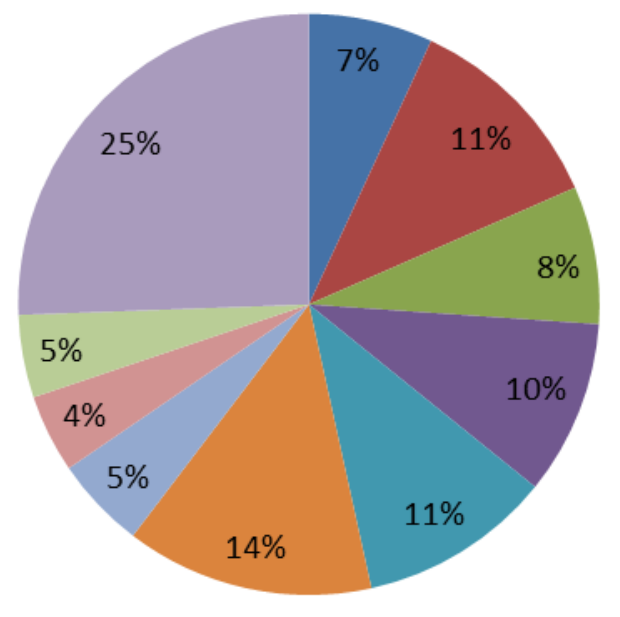

$$
\begin{aligned}
& \text { — Koszyce/Zalew Koszycki } \\
& \text { — Zielona Dolina } \\
& \text { — Jadwiżyn } \\
& \text { — Zamość } \\
& \text { — Podlasie } \\
& \text { — Górne } \\
& \text { — Motylewo } \\
& \text { — Dołki/Staszyce } \\
& \text { — Gładyszewo } \\
& \text { —Śródmieście/Centrum }
\end{aligned}
$$

Fig. 11. Interest in departing the night line from the district

In this case, the Śródmieście district also enjoys the greatest interest among potential passengers (23\%). People participating in the study were also largely interested in the arrival of night lines to such districts as Górne (14\%), Zielona Dolina (11\%) and Podlasie (11\%). Other districts received less than $10 \%$ of the respondents' answers. The results are presented in Figure 12. 


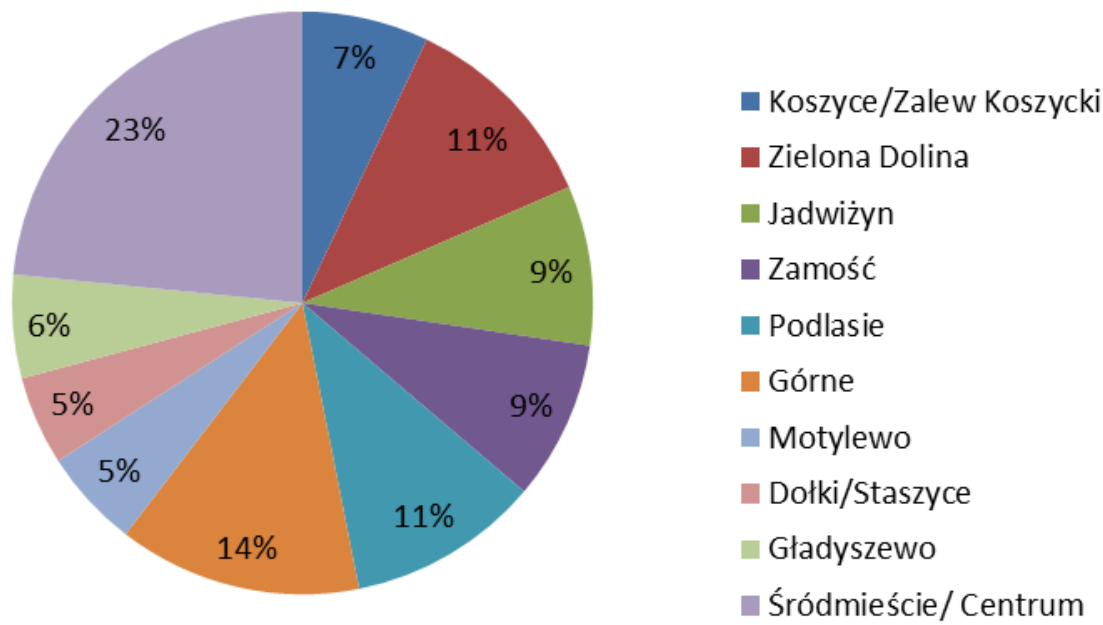

Fig. 12. Interest in the arrival of the night line to the district

The next question concerned the days of using public transport. People interested in using the night lines strongly indicated the answer "Friday-Saturday" (32\%) and "Saturday-Sunday" (29\%). This is the most frequently chosen time of the week when respondents can meet with friends and spend some time with them. Hence, the night life flourishes in the city. The results are presented in Figure 13.

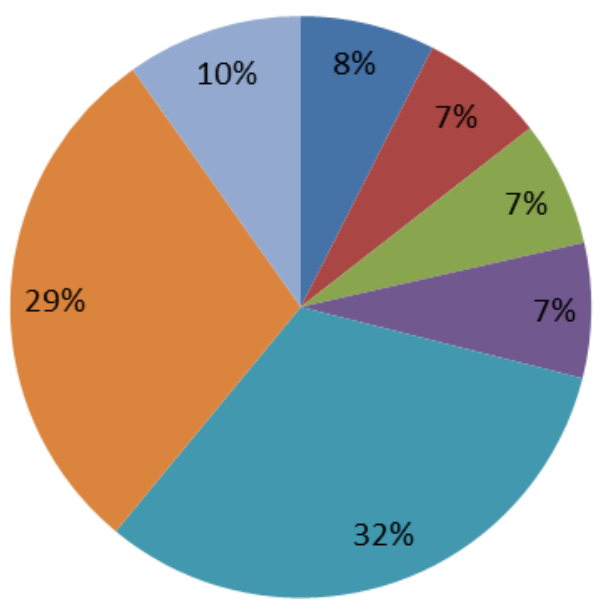

$$
\begin{aligned}
& \text { Monday-Tuesday } \\
& \text { Tuesday-Wednesday } \\
& \text { Wednesday-Thursday } \\
& \text { Thursday-Friday } \\
& \text { Friday-Saturday } \\
& \text { Saturday-Sunday } \\
& \text { Sunday-Monday }
\end{aligned}
$$

Fig.13. Days of passengers using the night lines in Piła

The last question was an open question and concerned comments on the survey of the respondent and the transport company. Comments from respondents:

- Introduction of night lines every 30-35 minutes.

- Introduction of daily lines to Dobrzyca.

- Introduction of ticket vending machines issuing the rest. 


\section{THE CONCEPT OF INTRODUCING NIGHT LINES IN PILA}

Based on the research conducted, the district that enjoys the greatest interest in departures and arrivals of night buses is the Śródmieście / Centrum district, that is, the place where Piła's nightlife mainly takes place. The next most frequently chosen districts are Zielona Dolina, Podlasie, Zamość and Górne. Due to the possibility of conducting tests in three different places, the following night lines were developed: N1 and N2. The N1 line would consist of 16 stops and connect the Zielona Dolina housing estate with the Górne housing estate. The N2 line would have 21 stops and would connect the Podlasie housing estate with the Górne housing estate.

When creating routes, districts such as Koszyce / Zalew Koszycki, Motylewo, Gładyszewo and Staszyce were excluded due to the low interest of the respondents. Night lines would intersect at Aleja Piastów/Hotel Gromada because it is the very center of the city. The map below presents 2 routes of night lines. Green is the N1 line while yellow is the N2 route (Figure 14).

The timetable and driving time were created based on this research. It was assumed that buses of Piła MTC run at an average speed of $40 \mathrm{~km} / \mathrm{h}$ and the route of lines N1 and N2 was carried by a passenger vehicle. The travel time of the N1 line from point A to point B is 19 minutes. The travel time of the $\mathrm{N} 2$ line from point A to point B is 24 minutes. Loop buses would run every 30 minutes. The courses are organized so that there is one bus and one driver per night line. Based on the research, it was proposed that the night lines should initially be introduced from Friday to Saturday and from Saturday to Sunday and run from 23:00 to 4:00 at night.

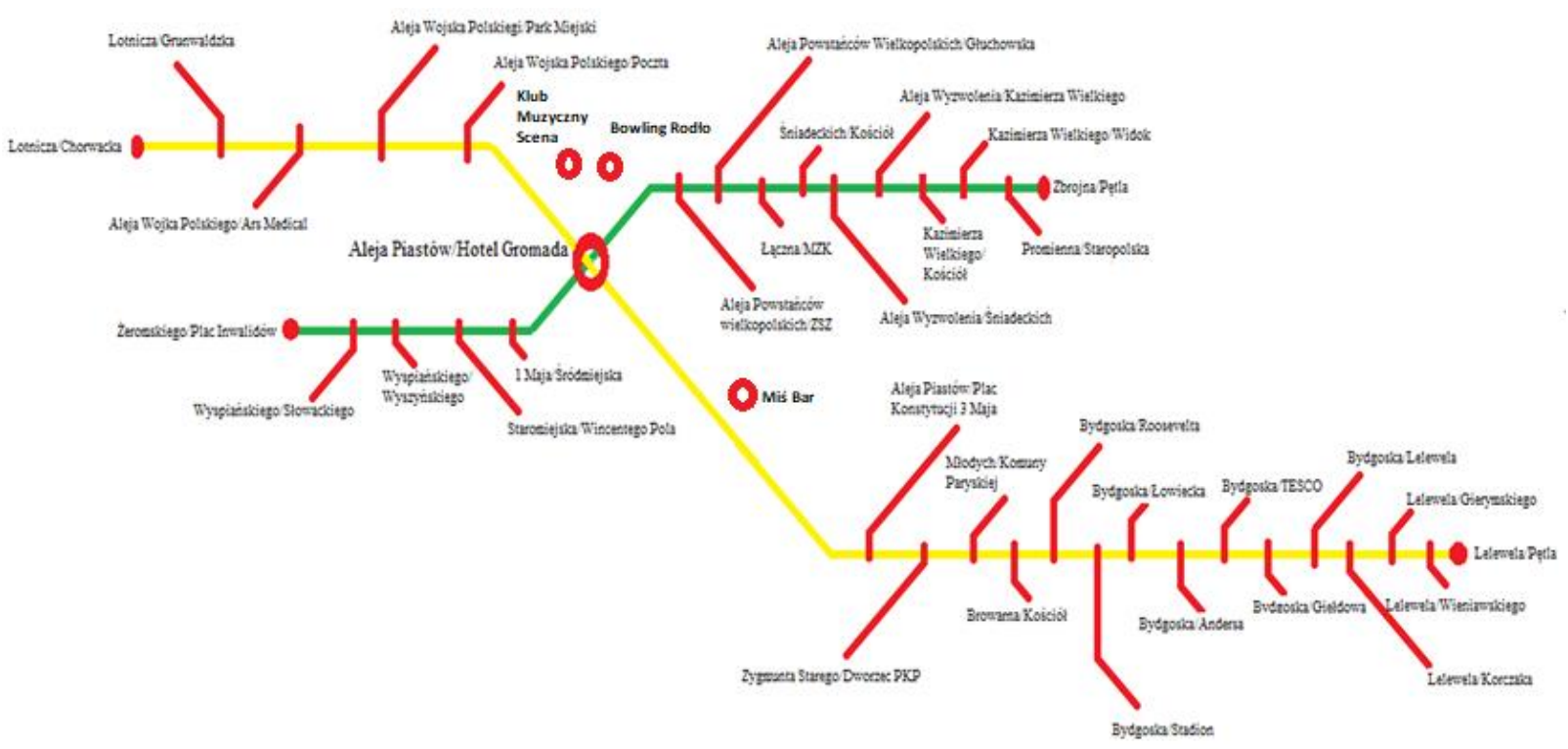

Fig. 14. Night lines route N1 and N2

In 2021, one hauler cost MTC 7.51 PLN. The route from point A to point B of the night line $\mathrm{N} 1$ is 8 kilometers, while the route from point A to point B of the night line N2 is 10 kilometers.

Based on the calculations used, the buses on the two night routes $\mathrm{N} 1$ and $\mathrm{N} 2$ cover a total of 24 routes from point A to point B and back, which gives 216 kilometers in one night. The projected cost of both lines in one weekend is PLN 3244.32. Assuming that on average there are four weekends a month, the forecast monthly costs are PLN 12,977.30. For the Municipal 
Transport Company in Piła to gain from night lines, a uniform rate of PLN 4 should be introduced. This means that 850 passengers should use it during the weekend. If the MTC had introduced a uniform ticket rate of 4.5 PLN, 750 people should use it during the weekend, and 680 passengers at 5 PLN, respectively, taking into account the cost of 1 car kilometer in 2021.

\section{SUMMARY}

To create effective urban logistics, that is, one that facilitates movement and does not cause transport difficulties, takes an adequate amount of time, people and financial outlays. Each element must cooperate with each other from the correct condition of roads, to people serving companies and transport to the right number of apartments. There are many links here, which at first glance seem insignificant.

Analyzing the activities of the Municipal Transport Company in Piła, one can observe its large development. The company invests in new vehicles every year, which ensures cleaner air. MTC started with several bus lines and currently has about 20 of them. A great opportunity for even faster development will be the introduction of electric vehicles in future years, for which the company has received large funding.

The idea that was proposed for the development of the city was the introduction of night lines. This will make the city more attractive, and maybe re-develop the nightlife that has recently disappeared.

This research shows that residents and visitors are interested in introducing night lines during two nights: Friday / Saturday and Saturday / Sunday. Thus, the introduction of 2 night lines at this time is justified. Presently, it is not profitable to introduce them on other days as the interest is low.

This research also asked about the introduction of a higher ticket price during the night course. This did not significantly change the interest of respondents who were still eager to use this type of solution.

\section{References}

1. Čambál M., V. Cibulka. 2008. Logistika výrobného podniku. [In Slovak: Logistics of a manufacturing company]. Bratislava: STU in Bratislave. 198 p. ISBN: 978-80-2272904-8.

2. Szymczak M. 2008. City logistics. Publisher of the Poznań University of Economics, Poznań.

3. Kiba-Janiak M., K. Cheba. 2010. „City Logistics versus Quality of Life in The Area of Public Transport After an Example of a Medium-Sized City". In: International Logistics and Supply Chain Congress 2010. Logistics Association Publication No: 9. Istanbul, Turkey.

4. Quak H. 2011. „Urban Freight Transport: The Challenge of Sustainability”. In: Macharis C., S. Melo (eds.). City Distribution and Urban Freight Transport: Multiple Perspective. Edward Elgar Publishing, Cheltenham. P. 37-55.

5. Covic F., S. Voß. 2019. "Interoperable smart card data management in public mass transit". Public Transport 11: 523-548. 
6. Taniguchi E., R.G. Thompson, T. Yamada. 2013. „Concepts and Visions for Urban Transport and Logistics Relating to Human Security". In: Taniguchi E., T.F. Fwa, R.G. Thompson (eds.). Urban Transportation and Logistics: Health, Safety, and Security Concerns. CRC Press, Boca Raton. P. 1-76.

7. Taniguchi E., R.G. Thompson, T. Yamada. 1999. „Modeling city Logistics”. In: Taniguchi E., R.G. Thompson (eds.). City Logistics. Institute of Systems Science Research. P. 3-37.

8. Szołtysek J. 2011. Creating mobility of city dwellers. Warsaw: Wolters Kulwer.

9. Załoga E., E. Dudek. 2009. „Selected problems of European society mobility”. Scientific Notebooks of the University of Szczecin, Problems of Transport and Logistics 9: 99-109.

10. Flejterski S., A. Panasiuk, J. Perenc, G. Rosa. 2008. Contemporary economics of services. Warsaw: PWN Scientific Publisher.

11. Menes E. 2001. ,Socio-economic aspects of the development of individual motorization in Poland". Communication Review 01.

12. Definition of the communication line. Available at: https://pl.wikipedia.org/wiki/Linia_komunikacyjna.

13. Definition of the timetable. Available at: https://pl.wikipedia.org/wiki/Rozkład_jazdy.

14. Information on night communication in the city of Warsaw. Available at: https://www.ztm.waw.pl/.

15. Information on night communication in the city of Poznan. Available at: https://www.ztm.poznan.pl/pl/komunikacja/.

16. Information on night communication in the city of Wroclaw. Available at: https://www.wroclaw.pl/komunikacja.

17. Information on public transport in the city of Piła during the Night of Museums. Available at: http://www.pila.pl/pl/aktualnosci/7164-noc-muzeow-2019.html.

18. Information about the city of Pila. Available at: https://pl.wikipedia.org/wiki/Piła_(miasto).

19. Information about the Municipal Transport Company in Pila. Available at: http://www.mzk.pila.pl/.

20. Chamier-Gliszczyński N. 2016. „A model of mobility of city users for the needs of transport activities". Urban And Regional Transport 6.

Received 15.09.2021; accepted in revised form 10.11.2021

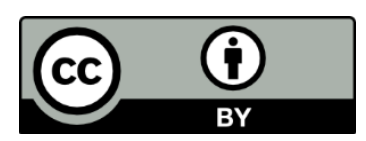

Scientific Journal of Silesian University of Technology. Series Transport is licensed under a Creative Commons Attribution 4.0 International License 